\title{
INVENTORY OF AND REHABIITIATION RECOMMENDATIONS FOR STTES DISTURBED BY MODERN MAN'S ACTIVITIES \\ IN GRAND TETON NATIONAL PARK
}

\author{
E. Durant McArthur \\ Stephen B. Monsen \\ Shrub Sciences Laboratory \\ Intermountain Research Station \\ USDA Forest Service \\ Provo, UT \\ A. Clyde Blauer \\ Division of Life Sciences \\ Snow College \\ Ephraim, UT
}

\section{Objectives}

This study has four principal objectives. The first was to locate and map the major areas in the Grand Teton National Park and the Rockefeller Memorial Parkway that have been disturbed or altered from their natural condition by modern man's activities. We were particularly concerned with those lands added to the Park in 1950 and up to the present.

The second objective was to document the nature and extent of the disturbance at each site, including date of disturbance and the historical context in which the disturbances occurred.

The third objective was to evaluate disturbed sites for cultural resource significance, whether or not artificial measures are needed to restore the sites to acceptable natural conditions, and how well they have progressed toward satisfactory restoration since they were disturbed.

The final objective was to develop general guidelines and site specific plans for restoring or rehabilitating disturbed sites using information from the scientific and applied management literature and information that can be obtained from the disturbed sites themselves as to expected rates of natural recovery and the effectiveness of artificial measures that have been used previously.

\section{Methods}

A preliminary survey was made of the Grand Teton National Park and the Rockefeller Parkway to identify disturbed areas and to select those for study. Consultation with Park personnel (Marshall Gingery, Asst. Superintendent; Robert Wood, Resources Management Specialist; Pete Hayden, Biologist; and William Barmore, Research Biologist) aided materially in making the final site selections. 
Sixteen areas were selected for study. Eleven of these areas had been used for farming or ranching and had received considerable disturbance. The remaining five areas, relatively undisturbed by modern man, were selected for comparative purposes to show the contrast between vegetation on the disturbed sites versus the more natural plant com munities of the undisturbed sites. The disturbed sites were selected to represent various degrees of disturbance and length of time since disturbance.

The sixteen study areas were plotted on topographic and orthophoto quadrangular maps, aerial photographs and on the 1968 1:62500 scale Geological Survey map of Grand Teton National Park.

Information on the history of the study sites was obtained from land status maps and from interviews with pertinent Park personnel and former land owners.

Each study area was subdivided into five or more fairly equal sections depending on the size of the area. A line of $50 \mathrm{~m}$ length was established by random starting points and random direction in five of the sections of each study area. In study areas with more than five sections, five sections were randomly selected for study. The vegetation along the lines was analyzed by using a one meter square quadrat which was laid on alternate sides of the tape every $5 \mathrm{~m}$ starting at $0 \mathrm{~m}$. Thus, 10 quadrats were "read" for each line. The number of individuals of each species within the quadrat was recorded. For rhizomatous species, 10 meter square samples from closed stands were sampled by counting each stem. A visual estimate of the area of the quadrat covered by the canopy of the species was also made (Daubenmire 1959). The following seven cover classes were used: 0-1 $8,1-5 \%, 5-25 \%, 25-50 \%, 50-75 \%, 75-95 \%$, and 95-100\%. The species were identified and classed as annuals, biennials, or perennials and whether they were native to the Park, native to North America, or alien following Hitchcock et al. (1955-1969), Cronquist et al. (1972-1984), and Shaw (1976). The cover classes of litter, rock, bare ground and cryptogams were recorded along with the aspect, slope, and direction of each line. Representative photographs were taken of the vegetation of each study site. The plant data will be analyzed for each species for the following characteristics: relative density, percent cover, relative dominance, frequency, and importance value (Cox 1967). Growth form (annual, biennial, perennial), and life form (herb, shrub, tree) have been recorded. Similarities will be determined first by pairwise group comparison tests (Woolf 1968), and then by cluster analysis (Ruzika 1958; Sokal and Sneath 1963).

Soil data from each site will be treated in the same manner, i.e. subjected to pairwise comparison and to cluster analysis.

In addition to data collection we made a reconnaissance trip to each site to determine possible rehabilitation options.

$\underline{\text { Results }}$

Quantative analyses have not been made, but the data is organized so that task can be accomplished. On a qualitative bases, the data is organized and is being 
provided to Grand Teton National Park officials simultaneously with this report. Our 16 sites (Table 1) range in size from about 30 acres to well over 2,000 acres and support from 8 to 74 species. Sites had as low as 2.1 percent to as high as 56.2 percent introduced plants. We inventoried and collected 215 species of vascular plants on our study sites including 42 grasses, all perennial and 78.6 percent native; 11 grasslike species, all perennial and native; 146 forbs, 16.0 percent annual, 4.2 percent biennial, 5.6 percent biennial-perennial; 74.3 percent perennial, and 84.7 percent native; 15 native shrubs; and one native tree. Herbarium specimens are deposited in the herbaria of Snow College and the Shrub Sciences Laboratory. We collected seven taxa that are new records for Grand Teton National Park (Table 2). We observed, but did not collect, another plant, intermediate wheatgrass (Agropyron intermedium) on some old hay fields, most notably the Cottonwood Creek hayfield. Finding this species in the Park area is not unexpected (Beetle 1977). Of these eight new plants, three are not native. The analysis of our synecological data will provide the basis for an examination on secondary succession in Jackson Hole to publish in a scientific journal article.

Soils for each site were located in the "Soil Survey of Teton County, Wyoming, Grand Teton National Park Area" (Young et al. 1982). Soil samples were collected from each study site and will be analyzed for phosphorus-bicarbonate extraction (Olsen et al. 1954); cation exchange capacity, potassium, calcium, and magnesium-ammonium acetate extraction (Schollenberger et al. 1945);calcium carbonate- $\mathrm{CO}_{2}$ evolution, pressure calcimeter (Black 1965); iron, zinc, copper, and manganese - modified D.P.T.A. extraction (Lindsay et al. 1978); pH-saturated paste (Schofield et al. 1955); total nitrogen-micro Kjeldahl (Bremner et al. 1960); texture-Bouyoucos hydrometer (Bouyoucos et al. 1926); percent gravel-sieve (American Society for Testing Materials 1961).

We have drafted a plan for Grand Teton National Park officials to consider in possible rehabilitation treatments of the disturbed study sites. This plant, including alternative treatments, was provided simultaneously with this report.

\section{Conclusions}

The data collected, when completely analyzed, will show rates of secondary succession in several big sagebrush communities and a lodgepole pine community in Jackson Hole. Procedures are available to return disturbed communities to more natural states, but some of those procedures may not be acceptable in the National Park setting. Two ancillary documents provide support for these conclusions and were provided to Grand Teton National Park officials.

\section{Literature Cited}

American Society for Testing and Materials. 1961. Tentative method for grain-size analysis of soils. In The 1961 Book of ASTM Standards, Part 4, p. $1272-1283$. 


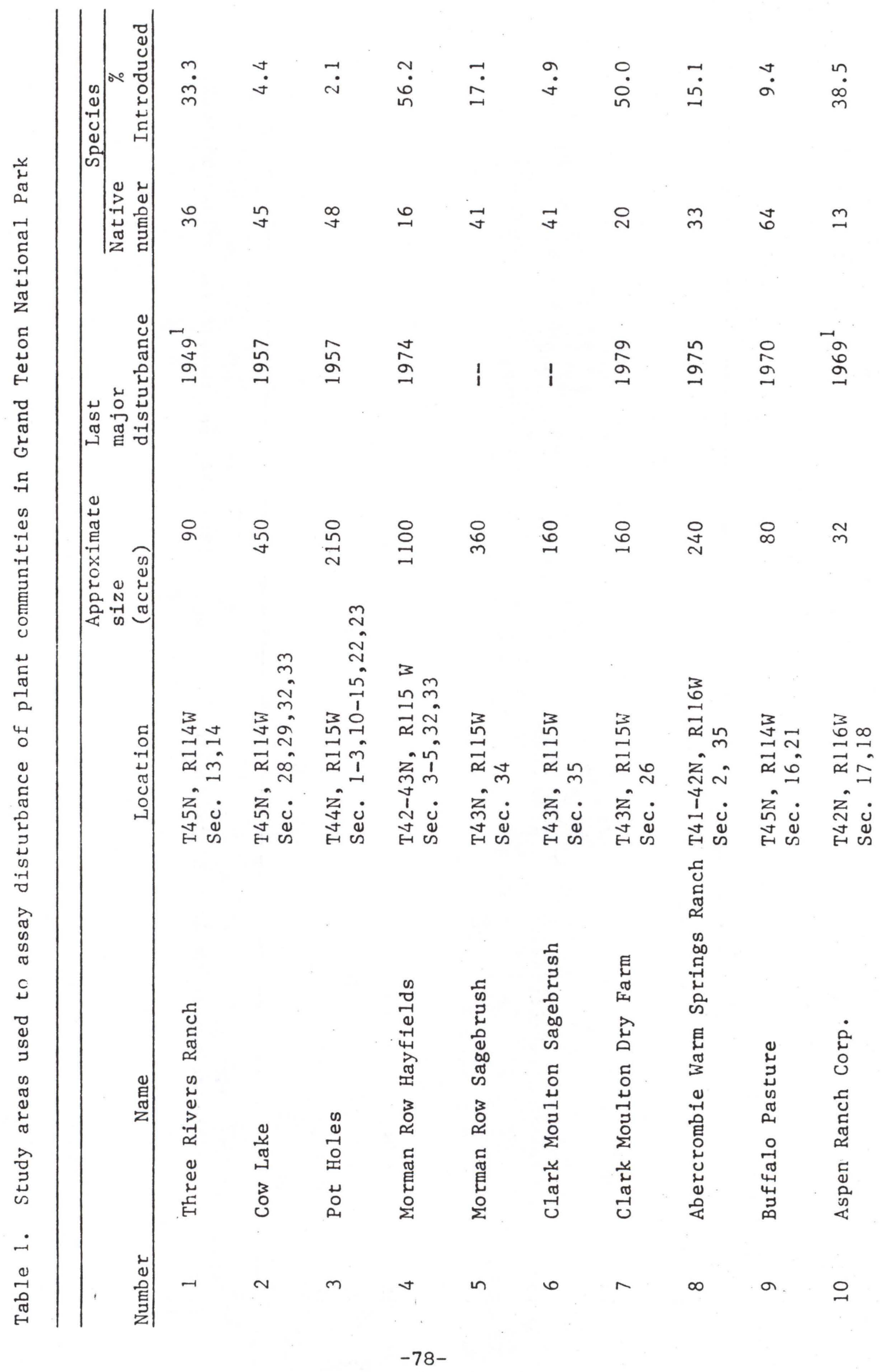




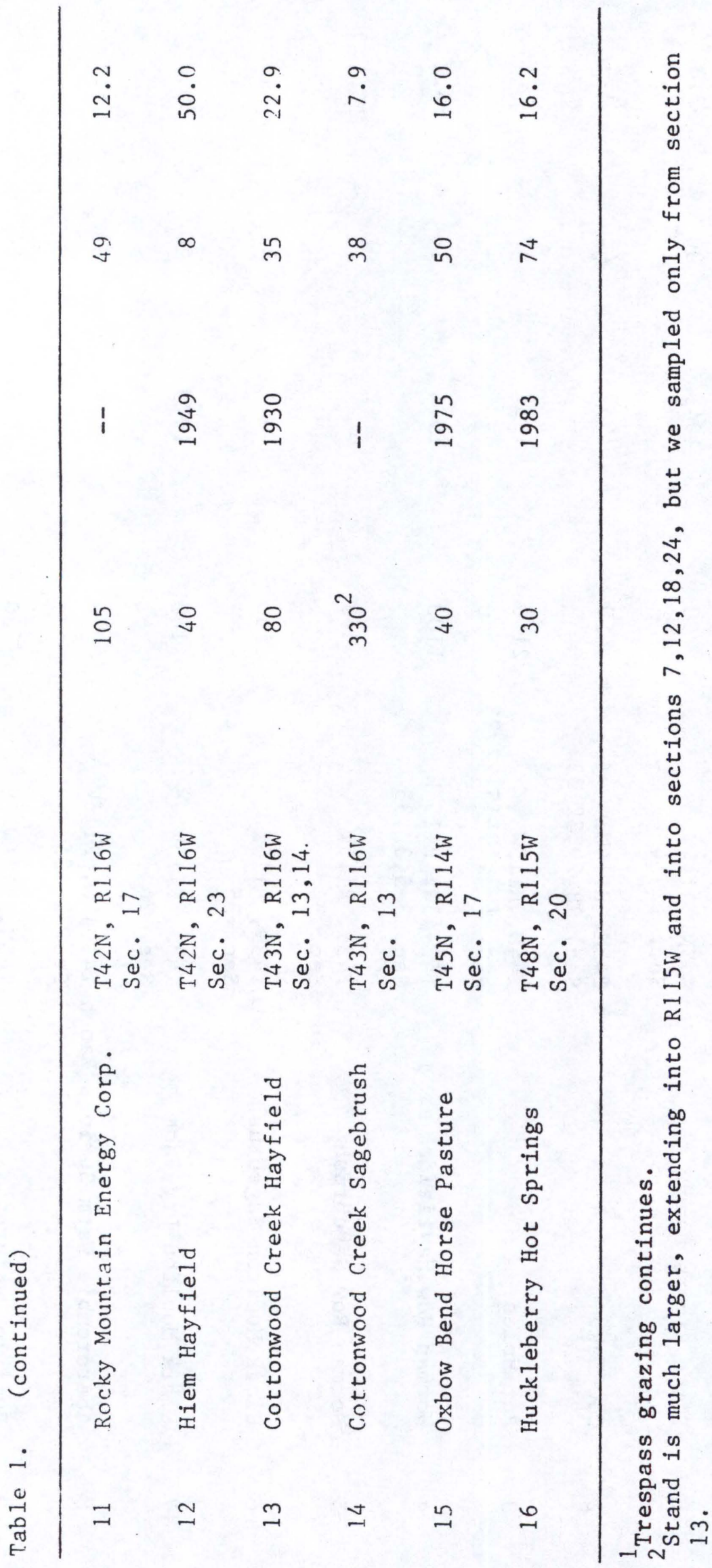


Table 2. New species found at Grand Teton National Park, Summer 1985.

Collection 非138

Collection 155

Collection $\#_{1} 174$

Collection 非12

Collections 非228 and 244

Collection 非 280

Collection 非362
Centaurea montana L. (mountain bluet). Alien from Europe growing in old ditch near disturbed lodgepole area, 3-Rivers Ranch. 13 July (not listed in Shaw 1976. Keyed out in Bailey's "Manual of Cultivated Plants", Bailey 1949).

Alisma gramineum Gmel. var. angustissimum (D.C.) Hendricks (water-plaintain). Growing on exposed bed of Jackson Lake in mud. North of Leek's Marina. 15 July. (Note 1isted in Shaw 1976. Keyed out in Hitchcock et al. 1955-1969).

Sanchus uliginosus Bieb. (sow thistle). Roadside weed along Gros Ventre Rd. in south end of Mormon Row. Alien from Europe. $25 \mathrm{July.} \mathrm{(Not} \mathrm{1isted} \mathrm{in}$ Shaw. Keyed out in Hitchcock et al. 1955-1969).

Astragalus convallarius Greene (timber poisonvetch). From former dry farm area now reverted to sagebrush. North side of section 35 next to Clark Moulton's Dry Farm. 26 July. (Not listed in Shaw 1976. Keyed out in Hitchcock et a1. 1955-1969.

Chrysothamnus viscidiflorus (Hook.) Nutt. ssp. puberulus $\mathrm{Hal} 1$ and Clements (hairy low rabbitbrush). Sagebrush flat in section 34 of Mormon Row. 29 July. (Not listed in Shaw 1976. Keyed out in McArthur et a1. 1979).

Rumex occidentalis Wats. (western dock). Grass/sedge meadow of Buffalo Pasture in Jackson Wildlife Park, National Environmental Study Area. (Not listed in Shaw 1976, keyed out in Hitchcock et a1. 1955-1969).

Lepidium virginicum L. var. pubescens (Greene) C. L. Hitchcock (Virginia pepperweed). Lodgepole pine forest, Huckleberry Hot Springs, Rockefeller Parkway. 16 August. (Not listed in Shaw 1976, keyed out in Hitchcock et al. 1955-1969). 
Baily, L. H. 1949. Manual of cultivated plants. MacMillian Publishing Co., New York.

Beetle, A. A. 1977. Grasses of Wyoming. Agric. Exper. Sta., Univ. of WY. Res. J. 39R Laramie.

Black, C. A., D. D. Evans, J. L. White, L. E. Ensminger, F. E. Clark (eds.) 1965. Methods of soil analysis. Part 2. Chemical and Microbiological Properties. Amer. Soc. of Agron., Madison, WI.

Brenner, J. M. 1960. Determination of nitrogen in soil by the Kjeldahl method. J. Agric. Sci. 55:11-33.

Bouyoucos, G. J. 1926. Estimation of the colloidal material in soils. Science $64: 362$.

Cox, G. W. 1967. Laboratory manual of general ecology. Wm. C. Brown Co. Publishers, Dubuque, IA.

Cronquist, A., A. H. Holmgren, N. H. Holmgren, J. L. Reveal, and P. K. Holmgren. 1972-1984. Intermountain flora, vascular plants of the Intermountain West, U.S.A. Columbia Univ. Press, New York.

Daubenmire, R. 1959. A canopy-coverage method of vegetational analysis. Northwest Sci. 33:43-64.

Hitchcock, C. L., A. Cronquist, M. Owenby, and J. W. Thompson. 1955-1969. Vascular plants of the Pacific Northwest. Univ. of W A Press, Seattle.

Lindsay, W. L., and W. A. Norvell. 1978. Development of a DTPA soil test for zinc, iron, manganese, and copper. Soil Sci. Sco. Am. J. 42:421-428.

McArthur, E. D., A. C. Blauer, A. P. Plummer, and R. Stevens. 1979. Characteristics and hybridization of important Intermountain shrubs. III. Sunflower family. USDA For. Serv. Res. Paper INT-220, Ogden, Utah.

Olsen, S. R., C. V. Cole, F. S. Watanabe, and L. A. Dean. 1954. Estimation of available phosphorus in soils by extraction with sodium bicarbonate. U.S. Dept. Agric. Circ. 939.

Ruzicka, M. 1958. Anwendung mathematisch-statistiker Methoden in Geobotanik. Biologia 13:647-661.

Shaw, R. J. 1967. Field guide to the vascular plants of Grand Teton National Park and Teton County, Wyoming. Utah State Univ. Press, Logan.

Schollenberger, C. J., and R. H. Simon. 1945. Determination of exchange capacity and exchangeable bases in soil-ammonium acetate method. Soil Sci. 59:13-24.

Sokal, R. R., and P. H. A. Sneath. 1963. Principles of numerical taxonomy. W. 
H. Freeman and Co., San Francisco.

Woolfe, C. M. 1968. Principles of biometry. D. Van Nostrand Co., Inc., Princeton, New Jersey.

Young, J. F., D. J. Lewis, C. J. Fowkes, and W. R. Glenn. 1982. Soil survey of Teton County, Wyorning, Grand Teton National Park area. USDA Soil Conservation Service. USDI Nat'l. Park Serv., and WY Agric. Exp. Sta., Laramie. 